\title{
UJI TOKSISITAS TERATOGENIK EKSTRAK ETANOL DAUN ASAM JAWA (Tamarindus indica Linn) TERHADAP TIKUS (Rattus norvegicus)
}

\author{
Sitti Rahimah, Mirnawati Salampe, Nurbaiti Rahmania
}

\author{
Sekolah Tinggi Ilmu Farmasi Makassar \\ Email : st.rahimah07@gmail.com
}

\begin{abstract}
In this study of teratogenic toxicity tests was carried out on the ethanol extract of tamarindus leaves (Tamarindus Indica Linn) on rats (Rattus norvegicus) during the organogenesis period. This study aims to know the safety and toxicity of the administration of ethanol extract of tamarind leaves (Tamarindus indica $L$.) to fetus rats (Rattus norvegicus) with macroscopic parameters including number, resorption, weight, and skeleton of the fetus. 15 animals were divided into 3 groups, each group consisted of 5 rats. Group I was treated with $0.5 \% \mathrm{Na} C M C$ as normal control, group II was treated with ethanol extract of tamarind leaves with a dose of $14 \mathrm{mg} / 200 \mathrm{~g} \mathrm{BW}$ for 10 days and group III was given a simvastatin tab at a dose of $10 \mathrm{mg} / \mathrm{kg} \mathrm{BW}$. Treatment was given orally during the organogenesis period on the 5th to 15th day of pregnancy. On the 16th day, laparatomy of the rat and fetus was removed from the uterus. The results showed that the suspension of ethanolic extract of tamarind leaves did not cause teratogenic occurrence in fetal rats, and the control of simvastatin caused teratogenic due to resorption, less fetal weight, hand and foot defect, and death in the fetus, compared to the normal control group.
\end{abstract}

Key words: Teratogenic, Tamarindus indica, Rattus norvegicus.

\section{PENDAHULUAN}

Alam Indonesia kaya akan beraneka ragam tumbuhan yang merupakan salah satu sumber senyawa kimia alam hayati yang dikenal dengan istilah "Natura Product Chemistry". Hingga kini, penggunaan bahanbahan alami untuk tujuan kesehatan masih terus dilakukan oleh masyarakat umum. Salah satu bahan alami yang dipercaya berperan pada kesehatan ialah daun asam jawa (Tamarindus indica L). ${ }^{1}$

Khasiat daun asam jawa untuk kesehatan juga telah banyak dipercaya oleh masyarakat. Penelitian yang telah dilakukan pada awalnya bertujuan untuk mengetahui isi dan kandungan dari daun asam jawa serta potensinya terhadap kesehatan. Salah satu hasil penelitian ekstrak etanol daun asam jawa (Tamarindus indica L) dengan konsentrasi ekstrak $2 \mathrm{mg} / 20 \mathrm{~g}$ BB memiliki kemampuan optimal dalam menurunkan kadar glukosa darah. $^{2}$

Penelitian yang dilakukan oleh Munim, dkk. ${ }^{3}$ menunjukkan bahwa ekstrak daun asam jawa memperlihatkan penghambatan $\alpha$ amilase, sehingga memiliki potensi sebagai alternatif pengobatan diabetes mellitus tipe 2 . Ekstrak daun asam jawa telah diidentifikasi mengandung senyawa golongan kimia flavonoid, tanin, glikosida dan saponin. Manfaat lain dari daun asam jawa merupakan antioksidan yang kuat, mempunyai aktifitas anti inflamasi, analgesik, anti alergi, anti obesitas, dapat menurunkan kadar gula darah, mempunyai aktifitas sebagai antibiotik, dapat mempengaruhi motilitas usus, juga berperan dalam menghambat pertumbuhan kanker. ${ }^{4}$ 
Terbatasnya bukti-bukti ilmiah mengenai tanaman tradisional memerlukan pengujian lebih lanjut mengenai khasiat dan toksisitas tanaman tradisional tersebut. Uji toksisitas dilakukan sebagai langkah awal setelah obat tradisional tersebut terbukti berkhasiat. Penelitian yang dilakukan oleh Jemita Mangande dan Fernando, mengenai uji toksisitas subkronik ekstrak etanol daun asam jawa (Tamarindus indica L.) selama 30 hari terhadap tikus putih jantan (Rattus norvegicus) pada dosis $14 \mathrm{mg} / 200 \mathrm{~g} \mathrm{BB}$ menunjukkan tidak terjadinya efek toksik terhadap hati maupun pada ginjal. ${ }^{5,6}$

Uji teratogenik merupakan uji yang harus dikerjakan bila pemakaian klinis obat diberikan pada masa-masa organogenesis selama kehamilan. Efek teratogenik obat tradisional diketahui terjadi pada banyak kasus, hal ini karena zat kimia yang terdapat dalam obat tradisional ditransportasikan melalui plasenta yang dapat menyebabkan efek toksik pada pertumbuhan janin yang sensitive. ${ }^{7}$ Uji ini penting dilakukan mengingat kemungkinan konsumen pemakainya ialah wanita hamil yang menggunakan tanaman tersebut sebagai suplemen tambahan dan menjaga kesehatan tubuh. $^{8}$

\section{METODE PENELITIAN}

Bahan : bahan yang digunakan dalam penelitian ini adalah ekstrak daun asam jawa (Tamarindus indica L.), simvastatin tab, etanol $70 \%, \mathrm{NaCl} 0,9 \%$, eter, hidrogen peroksida $1 \%$, thatharazin, gliserin, asam sulfat, asam asetat, kapas, $\mathrm{Na}$. CMC, tissue, sarung tangan.

\section{Prosedur kerja}

\section{Pengolahan}

Sampel daun tanaman asam jawa (Tamarindus indica L.) disortasi basah kemudian dikeringanginkan, dan dilakukan sortasi kering untuk memisahkan sisa-sisa kotoran. Simplisia daun asam jawa (Tamarindus indica L.) selanjutnya ditimbang sebanyak 500 gram diekstraksi dengan 5 Liter etanol $70 \%$ selama $3 \times 24$ jam, sambil sesekali diaduk Setelah itu filtrat yang diperoleh dikumpulkan dan diuapkan menggunakan rotary evaporator hingga diperoleh ekstrak kental. $^{3}$

\section{Pembuatan Larutan Uji}

Larutan kontrol Normal (Na-CMC 0,5\%): Na.CMC ditimbang sebanyak 0,5 gram, kemudian dimasukkan sedikit demi sedikit ke dalam $60 \mathrm{~mL}$ air panas $\left(70^{\circ} \mathrm{C}\right)$ diaduk hingga terbentuk larutan koloidal dan dicukupkan volumenya hingga $100 \mathrm{~mL}$.

Suspensi ekstrak 14 mg/200 g BB: Untuk penggunaan dosis $14 \mathrm{mg} / 200 \mathrm{~g}$ BB yaitu ekstrak etanol daun asam jawa ditimbang 210 $\mathrm{mg}$, kemudian disuspensikan ke dalam $30 \mathrm{~mL}$ $\mathrm{Na.CMC}$ diaduk hingga homogen.

Suspensi kontrol Simvastatin: Untuk penggunaan dosis $10 \mathrm{mg} / \mathrm{kg} \mathrm{BB}$, serbuk simvastatin ditimbang $14,5 \mathrm{mg}$ kemudian disuspensikan ke dalam $10 \mathrm{~mL}$ Na.CMC diaduk hingga homogen.

\section{Perlakuan Hewan Uji}

Hewan coba dibagi menjadi 3 kelompok, tiap kelompok terdiri dari 5 ekor tikus betina yang akan dihamilkan. Hewan uji diberikan makanan dan minuman secara normal kemudian masing-masing tikus putih betina ditimbang bobot badannya. Kelompok I kontrol normal (larutan Na.CMC) kelompok II diberikan ekstrak daun asam jawa dan kelompok III kontrol simvastatin. Pemberian bahan uji dilakukan setiap hari dimulai pada hari ke 5 sampai hari ke 15 kehamilan dan diberi secara oral. Setelah itu tikus dibedah pada hari ke $16 .^{9}$ 


\section{Penentuan Awal Kehamilan.}

Pembuktian perkawinan dengan cara: setiap tikus betina diamati vaginanya dan tikus dinyatakan kawin bila ditemukan sumbat vagina. Bila tidak ditemukan, maka dilanjutkan dengan pembuatan apusan vagina dan tikus dinyatakan kawin bila ditemukan sperma dalam cairan apusan vagina. Adanya sumbat vagina atau sperma pada tikus betina dihitung sebagai kebuntingan hari ke nol. ${ }^{10}$

\section{Pembedahan Tikus}

Pembedahan dilakukan pada umur kehamilan 16 hari, tikus mula-mula ditimbang (bobot akhir) dan kemudian dibius dengan eter dan diletakkan terlentang diatas papan bedah, tangan dan kakinya masing-masing diikat pada jarum yang tertancap pada papan bedah. Kulit daerah dada dipotong dengan ujung gunting dan mula-mula digunting kearah unus, kemudian kearah mulut. Kulit dibuka dengan menggunting ujungnya dan uterus kemudian diemersikan kedalam larutan $\mathrm{NaCl}$ 0,9\%. ${ }^{11}$

\section{Perlakuan Terhadap Fetus ${ }^{10}$}

1. Penyimpanan: Fetus difiksasi dalam larutan etanol $90 \%$ selama 5 hari. Setelah dikeringkan fetus diikuliti dengan sempurna.

2. Pemutihan: Fetus dibilas dengan air dan sisa lemak dibuang. Air kemudian diganti dengan larutan hydrogen peroksida $1 \%$.

3. Pewarnaan : Setelah pemutihan sempurna, fetus dibilas dan direndam dalam air selama \pm 10 menit. Air kemudian diganti dengan larutan pewarna thatharazin.

4. Penilaian kerangka : Penilaian dilakukan setelah preparat di rendam dalam gliserin selama paling sedikit 2 hari.

\section{HASIL DAN PEMBAHASAN}

Pada penelitian ini dilakukan ekstraksi simplisia daun asam jawa menggunakan metode maserasi. Dari hasil ekstraksi diperoleh ekstrak kental sebanyak 52,43 gram dan berwarna coklat gelap dengan nilai rendamen sebesar $10,48 \%$.

Selanjutnya dilakukan uji bebas etanol pada ekstrak, uji ini dilakukan sebelum pemberian ekstrak (perlakuan) pada hewan coba tikus putih (Rattus norvegicus), untuk membebaskan ekstrak dari etanol sehingga didapatkan ekstrak yang murni tanpa ada kotaminasi, selain itu kandungan etanol dalam ekstrak juga akan mempengaruhi hasil karena dapat mengakibatkan kelainan janin seperti kelainan mikrosefali, celah langit, kelainan kardiovaskuler, janin tumbuh lambat dan retardasi mental. Diduga etanol menyebabkan defisiensi nutrient pada ibu atau memang berefek toksik langsung pada jaringan embrio. ${ }^{12}$ Hasil dari uji bebas etanol ekstrak yaitu tidak tercium bau ester yang khas menunjukkan bahwa ekstrak kental daun asam jawa positif bebas etanol.

Penelitian ini menggunakan tikus putih betina, tikus putih dipilih karena mempunyai kemiripan dengan manusia dalam hal fisiologi, anatomi, nutrisi, patologi atau metabolisme ${ }^{13}$ yang sebelumnya telah diadaptasikan dengan lingkungan kandang selama 5 hari untuk menyeragamkan cara hidup dan makanan hewan uji. ${ }^{11}$ serta meminimalisasi efek stres pada tikus yang berpengaruh pada metabolisme yang dapat mengganggu penelitian. ${ }^{14}$

Pada perkembangan embrio mamalia terjadi multiplikasi sel yang cepat, yaitu mulai dari zigot sampai terbentuknya lapisan germinal yang disebut stadium pra lapisan germinal atau stadium pradifferensiasi. Setelah itu disebut stadium embrio, dimana sel-sel embrio mulai memperlihatkan perbedaan 
morfologinya disebabkan perbedaan kimia yang dikandungnya. Akhirnya adalah stadium fetus, yang tampak adanya pertumbuhan sistem organ. ${ }^{15}$

Tikus diberikan larutan uji selama masa organogenesis yaitu hari ke 6 sampai 15 kehamilan. Pada hari ke 1 sampai hari ke 5 kehamilan, induk tikus tidak diberikan perlakuan karena pada saat itu terdapat sifat totipotensi pada fetus yang dapat memperbaiki jaringan rusak. Pada hari ke 16 dan seterusnya, senyawa teratogen tidak menyebabkan cacat morfologis, tetapi mengakibatkan kelainan fungsional yang tidak dapat dideteksi segera setelah kelahiran. ${ }^{16}$

Tabel 1. Jumlah janin dan resorp setiap kelompok

\begin{tabular}{|c|c|c|c|c|c|c|}
\hline Kelompok & $\begin{array}{l}\text { Jumlah induk } \\
\text { (Ekor) }\end{array}$ & $\begin{array}{l}\text { Total } \\
\text { janin }\end{array}$ & $\begin{array}{l}\text { BB rata-rata } \\
\text { janin (gram) }\end{array}$ & $\begin{array}{c}\text { Janin hidup } \\
\text { (Ekor) }\end{array}$ & $\begin{array}{c}\text { Janin mati } \\
\text { (mati) }\end{array}$ & $\begin{array}{l}\text { Resorp } \\
\text { janin }\end{array}$ \\
\hline Kelompok I & 5 & 36 & 5,199 & 36 & 0 & 0 \\
\hline Kelompok II & 5 & 34 & 5,198 & 34 & 0 & 0 \\
\hline Kelompok III & 5 & 22 & 4,460 & 10 & 12 & 5 \\
\hline
\end{tabular}

Pengamatan berat badan induk selama masa kehamilan menunjukkan adanya peningkatan yang disebabkan perkembangan fetus dan bertambahnya volume cairan amnion, plasenta serta selaput amnion. ${ }^{17}$ Selama pengamatan tidak ditemukan induk tikus yang mengalami kelahiran spontan dan diketahui dari tabel 1 bahwa pemberian ekstrak etanol daun asam jawa dengan dosis $14 \mathrm{mg} / 200 \mathrm{~g}$ BB tidak mempengaruhi jumlah kematian fetus dan tidak mempengaruhi kondisi lambat pertumbuhan janin, hal tersebut sama dengan hasil kontrol normal yang hanya diberikan larutan pembawa Na. CMC 0,5\%. Kelompok tikus yang diberikan simvastatin dengan dosis $10 \mathrm{mg} / \mathrm{kg} \quad B B$ mengalami kematian fetus sebanyak 12 dan resorpsi ditemukan sebanyak 5 . Fetus yang mengalami kematian kemungkinan disebabkan oleh kematian sel-sel pada tahap akhir proliferasi sehingga hanya sebagian sel yang dapat diperbaiki, ditambah lagi pada saat pembedahan kemungkinan proses reabsorpsi oleh induk belum sempurna sehingga keadaan fetus menjadi cacat. ${ }^{18}$
Berdasarkan dosis pemberiannya agen teratogen dosis rendah akan menyebabkan kematian beberapa sel dan akan terjadi pergantian sel tetangganya dengan hiperplasia kompensatorik sehingga terjadi fetus yang normal secara morfologis, akan tetapi ukurannya tetap kecil. ${ }^{19}$ Kompensasi sel itu terus berlangsung selama periode organogenesis, agar terjadi morfogenesis yang normal akan tetapi bila kompensasi itu gagal dan tidak dapat mencapai target pada tahap organogenesis maka akan terjadi malformasi atau cacat bawaan. ${ }^{20}$ Agen teratogenik dosis tinggi akan menyebabkan kematian sel dalam jumlah tinggi sehingga terjadi embrioletalis. ${ }^{21}$

Pengamatan secara morfologi meliputi pengamatan kelengkapan dan kelaian fetus. Untuk melihat ada atau tidaknya cacat luar tubuh janin pengamatan meliputi kelengkapan mulai dari kepala sampai ekor (mata, tangan, kaki, jari, telinga, dan ekor) pengamatan dilakukan secara makroskopis, yaitu dengan menggunakan mata.

Salah satu faktor penentu dalam proses pertumbuhan dan perkembangan 
Uji Toksisitas Teratogenik Ekstrak Etanol Daun Asam Jawa (Tamarindus indica Linn) Terhadap Tikus (Rattus norvegicus)

tulang adalah hormon. Hormon yang mempengaruhi pembentukan rangka di antaranya adalah $\mathrm{GH}$, tiroksin, estrogen, dan androgen. Hormon pertumbuhan $(\mathrm{GH})$ dihasilkan dari kelenjar hipofisis yang berfungsi untuk meningkatkan proses mitosis dari kondrosit dan osteoblas serta meningkatkan sintesis protein pembentuk kolagen, matriks kartilago, serta enzim untuk pembentukan kartilago dan tulang. Tiroksin dihasilkan dari kelenjar tiroid, berperan dalam meningkatkan proses sintesis protein. Estrogen berfungsi dalam menstimulasi aktivitas osteoblas dan proses sintesis matriks tulang. ${ }^{21}$

Tabel 2. Hasil pengamatan morfologi dan skeletal fetus

\begin{tabular}{|c|c|c|c|c|c|c|c|c|}
\hline \multirow{2}{*}{ Kelompok } & \multirow{2}{*}{ Tikus } & \multirow{2}{*}{ Mata } & \multirow{2}{*}{ Telinga } & \multirow{2}{*}{ Kaki } & \multirow{2}{*}{ Tangan } & \multicolumn{2}{|c|}{ Panjang fetus } & \multirow{2}{*}{ Kecacatar } \\
\hline & & & & & & Badan & Ekor & \\
\hline \multirow{5}{*}{ Kelompok I } & 1 & $\sqrt{ }$ & $\sqrt{ }$ & $\sqrt{ }$ & $\sqrt{ }$ & $3 \mathrm{~cm}$ & $1,2 \mathrm{~cm}$ & 0 \\
\hline & 2 & $\sqrt{ }$ & $\sqrt{ }$ & $\sqrt{ }$ & $\sqrt{ }$ & $3 \mathrm{~cm}$ & $1,2 \mathrm{~cm}$ & 0 \\
\hline & 3 & $\sqrt{ }$ & $\sqrt{ }$ & $\sqrt{ }$ & $\sqrt{ }$ & $3 \mathrm{~cm}$ & $1,2 \mathrm{~cm}$ & 0 \\
\hline & 4 & $\sqrt{ }$ & $\sqrt{ }$ & $\sqrt{ }$ & $\sqrt{ }$ & $3 \mathrm{~cm}$ & $1,2 \mathrm{~cm}$ & 0 \\
\hline & 5 & $\sqrt{ }$ & $\sqrt{ }$ & $\sqrt{ }$ & $\sqrt{ }$ & $3 \mathrm{~cm}$ & $1,2 \mathrm{~cm}$ & 0 \\
\hline \multirow{5}{*}{ Kelompok II } & 1 & $\sqrt{ }$ & $\sqrt{ }$ & $\sqrt{ }$ & $\sqrt{ }$ & $3 \mathrm{~cm}$ & $1,2 \mathrm{~cm}$ & 0 \\
\hline & 2 & $\sqrt{ }$ & $\sqrt{ }$ & $\sqrt{ }$ & $\sqrt{ }$ & $3 \mathrm{~cm}$ & $1,2 \mathrm{~cm}$ & 0 \\
\hline & 3 & $\sqrt{ }$ & $\sqrt{ }$ & $\sqrt{ }$ & $\sqrt{ }$ & $3 \mathrm{~cm}$ & $1,2 \mathrm{~cm}$ & 0 \\
\hline & 4 & $\sqrt{ }$ & $\sqrt{ }$ & $\sqrt{ }$ & $\sqrt{ }$ & $3 \mathrm{~cm}$ & $1,2 \mathrm{~cm}$ & 0 \\
\hline & 5 & $\sqrt{ }$ & $\sqrt{ }$ & $\sqrt{ }$ & $\sqrt{ }$ & $3 \mathrm{~cm}$ & $1,2 \mathrm{~cm}$ & 0 \\
\hline \multirow{5}{*}{ Kelompok III } & 1 & $\sqrt{ }$ & $\sqrt{ }$ & $x$ & $\sqrt{ }$ & $2,5 \mathrm{~cm}$ & $1 \mathrm{~cm}$ & 1 \\
\hline & 2 & $\sqrt{ }$ & $\sqrt{ }$ & $x$ & $x$ & $2,7 \mathrm{~cm}$ & $1 \mathrm{~cm}$ & 2 \\
\hline & 3 & $\sqrt{ }$ & $\sqrt{ }$ & $x$ & $x$ & $2,7 \mathrm{~cm}$ & $1 \mathrm{~cm}$ & 2 \\
\hline & 4 & $\sqrt{ }$ & $\sqrt{ }$ & $x$ & $x$ & $2,5 \mathrm{~cm}$ & $1 \mathrm{~cm}$ & 2 \\
\hline & 5 & $\sqrt{ }$ & $\sqrt{ }$ & $x$ & $\sqrt{ }$ & $2,7 \mathrm{~cm}$ & $1 \mathrm{~cm}$ & 1 \\
\hline
\end{tabular}

Keterangan: $\sqrt{ }=$ Ada; $X=$ Tidak ada

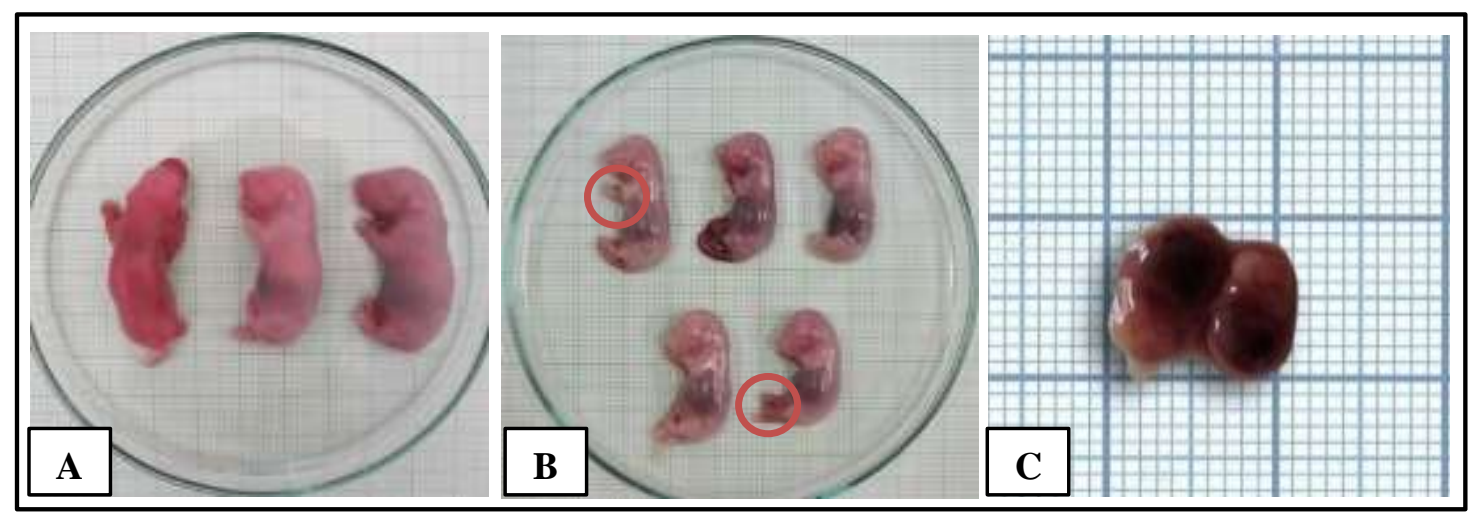

Gambar 1. Hasil Pengamatan Morfologi dan Skeletal Fetus (A) Fetus normal; (B) Fetus malformasi; (C) Resorp fetus.

Hormon pertumbuhan sangat penting karena akan mempengaruhi metabolisme protein, elektrolit, karbohidrat, dan lemak. ${ }^{22}$ Dari hasil pemeriksaan secara makroskopis bahwa pemberian ekstrak etanol daun asam jawa dengan dosis $14 \mathrm{mg} / 200 \mathrm{~g}$ BB tidak mempengaruhi kondisi lambat pertumbuhan janin seperti mata, telinga, jari-jari tangan dan kaki, hal tersebut sama dengan hasil kontrol normal yang hanya diberikan larutan pembawa Na. CMC 0,5\% tidak mempengaruhi kondisi lambat pertumbuhan janin tidak mempengaruhi 
bobot fetus dan tidak mempengaruhi kondisi lambat pertumbuhan janin seperti mata, telinga, jari-jari tangan dan kaki. Simvastatin dengan dosis $10 \mathrm{mg} / \mathrm{kg}$ BB mengalami kecacatan pada fetus berupa adanya ditemukan kecatatan pada tangan dan kaki fetus. Berdasarkan studi pada binatang percobaan pengunaan simvastatin pada masa pregnancy telah memperlihatkan adanya kelainan janin (abnormalitas) atau terbukti beresiko terhadap janin, simvastatin dimasukkan kedalam obat kategori $X$ merupakan kontraindikasi bagi wanita hamil .23 Selama masa kehamilan aktivitas reduktase HMG-CoA diperlukan untuk perkembangan plasenta normal pada mamalia. Penghambatan reduktase HMG-CoA oleh statin dapat mengganggu sintesis membran, proliferasi dan pertumbuhan sel, metabolisme dan glikosilasi protein, yang sangat penting untuk perkembangan normal fetus. ${ }^{24}$ Hasil Penelitian yang telah dilakukan telah menunjukkan bahwa simvastatin menghambat migrasi in vitro dari sitotrofoblas extravillous ke Matrigel dan proliferasi sitotrofoblas vili. Ini juga meningkatkan apoptosis sel sitotrofoblas dan mengurangi sekresi progesteron. Penurunan simvastatin yang diinduksi dalam migrasi trofoblas tampaknya disebabkan oleh berkurangnya ekspresi reseptor IGF-1 membran dan HSP27 dan berkurangnya aktivitas MMP2 metalloproteinase. ${ }^{25}$

Menurut Hafez, (1980) penyusutan bobot dan panjang fetus merupakan bentuk teringan dari ekspresi teratogen sehingga mampu menjadi indikator terjadinya hambatan pertumbuhan akibat ganguan terhadap prosesproses yang mendasari pertumbuhan seperti pembelahan sel, metabolisme, dan sintesis di dalam sel. ${ }^{26}$

\section{KESIMPULAN}

Berdasarkan hasil pengamatan penelitian dan pembahasan maka dapat disimpulkan pemberian ekstrak daun asam jawa (Tamarindus indica L.) dosis $14 \mathrm{mg} / 200 \mathrm{~g}$ BB selama masa organogenesis tidak memiliki efek teratogenik terhadap fetus tikus putih (Rattus norvegicus).

\section{DAFTAR PUSTAKA}

1. Ranjan R, Swarup D, Patra RC, Chandra V. Tamarindus indica $\mathrm{L}$. and Moringa oleifera M. extract administration ameliorates fluoride toxicity in rabbits. Indian J Exp Biol. 2009;47(11):900-5.

2. Wiyandani AM. Pengaruh Ekstrak Daun Asam Jawa (Tamarindus indica L.) Terhadap Kadar Gula Darah Mencit (Mus musculus L.) Jantan Diabetes Mellitus Dan Pemanfaatannya Sebagai Buku Ilmiah Populer (Skripsi). Jember : Universitas Jember, 2016.

3. Munim A, Hanani E, Rahmadiah. Karakterisasi Ekstrak Etanolik Daun Asam Jawa (Tamarindus indica L.). Majalah IImu Kefarmasian. 2009;4(1):38-44.

4. Putri $\mathrm{CRH}$. The Potency And Use Of Tamarindus indica On Various Therapies. Jurnal IImiah Kedokteran. 2014;3(2):40-54.

5. Fernando. Uji Toksisitas Subkronik Ekstrak Etanol Daun Asam Jawa (Tamarindus indica Linn.) Terhadap Ginjal Tikus Putih (Rattus norvegicus) dengan Parameter Kreatinin (Skripsi), 2018.

6. Mangande J. Uji Toksisitas Subkronik Ekstrak Etanol Daun Asam Jawa (Tamarindus indica Linn.) Terhadap Organ Hati Tikus Putih Jantan dengan Parameter AST/ALT (Skripsi). 2017.

7. Azaizeh H, Saad B, Cooper E and Said O. Traditional Arabic and Islamic Medicine, a Re-emerging Health Aid. Evid Based Complement Alternat Med. 2010;7(4):419424.

8. Christianty FM and Winarti L. Uji Teratogenik Campuran Serbuk Biji Jinten Hitam (Nigella sativa L.), Biji Klabet (Trigonella foenum-graecum L.), dan Ginseng (Panax ginseng C. A. Mey.) Pada 
Tikus Putih Galur Wistar. Stomatognatic. 2012;9(3):155.

9. OECD (Organization for Economic Cooperation and Development). Oecd Guideline for the Testing of Chemicals, (January) 2001,p. 1-13.

10. Almahdy A. Uji Aktivitas Vitamin A Terhadap Efek Teratogen Warfarin pada Fetus Mencit Putih. Medan : USU Press., 2011.

11. Malole MBM, Pramono CSU. Pengantar Hewan-hewan Percobaan di Laboratorium. Bogor : Pusat Antara Universitas Bioteknologi IPB, 1989.

12. Davis DM. Textbook of Adverse Drug Reactions. New York : Oxford University Press., 1977.

13. Santoso HB. Pengaruh Kafein terhadap Penampilan Reproduksi dan Perkembangan Skeleton Fetus Mencit (Mus musculus L.) (Thesis). Yogyakarta: Universitas Gadjah Mada, 2006.

14. Gustiansyah RJ. Farmakologi dan Terapeutik. Jakarta : Fakultas Kedokteran Universitas Indonesia. 2009.

15. Syahrum, Hatta M. Reproduksi dan Embriologi: Dari Satu Sel Menjadi Organisme. Jakarta : Fakultas Kedokteran UI, 1994.

16. Lu FC. Toksikologi Dasar, Asas, Organ Sasaran dan Penilaian Resiko, Edisi II. Jakarta : Penerbit UI, 1995.

17. Guyton AC.Buku Ajar Fisiologi Kedokteran. Diterjemahkan Oleh Tenyadi K.A. Bagian III. Jakarta: UI. 1983.
18. Widiyani $T$ dan Sagi $M$. Pengaruh Aflatoksin B1 Terhadap Pertumbuhan dan Perkembangan Embrio dan Skeleton Fetus Mencit (Mus musculus). Journal of Technosains. 2001;24(3):409-427.

19. Ritter EJ. Altered Biosynthesis In: Wilson J.G., Fraster F.C. (eds). Handbook of Teratology. New York : Plenum Press., 1977.

20. Tuchman D. Drug Effect on The Fetus. New York-London : Adi Press., 1975

21. Scanlon VC, Sanders T. Buku Ajar Anatomi Dan Fisiologi (Essentials of Anatomy and Physiology); Edisi III, cetakan pertama. Jakarta : Penerbit Buku Kedokteran EGC, 2007.

22. Ganong W. Buku Ajar Fisiologi Kedokteran. Djauhari HM, Widjajakusumah, editor. Brahman U Pendit, penerjemah. Jakarta (ID): EGC., 2002.

23. Aberg JA, et al. Drug Information Handbook, 17th edition. Lexi-Comp for the American Pharmacists Association, 2009

24. Kazmin A, et al. Risks of statin use during pregnancy: a systematic review. J Obstet Gynaecol Can. 2007;29 (11): 906-8

25. Kenis I, et al. Simvastatin has deleterious effects on human first trimester placental explants. Hum Reprod. 2005; 20 (10): 2866-72

26. Hafez ESE. Functional Anatomi of Female Reproduction. Dalam: Hafez ESE (editor). Reproduction in Farm Animal. Philadelphia : Lea \& Febiger, 1980. Pp. 30-36. 